\title{
Modern China's Idols: Heroes, Role Models, Stars and Celebrities
}

\author{
Elaine Jeffreys, University of Technology Sydney
}

This paper examines a virtual commemorative artefact called 'The Search for Modern China' to consider the evolution of celebrity in the People's Republic of China (PRC). The website was launched in late September 2009 by Sohu.com, China's biggest Internet media company, to commemorate the sixtieth anniversary of the founding of the PRC under the leadership of the Chinese Communist Party (CCP) on 1 October 1949 ('Zhuixun xiandai Zhongguo’ 2009). As with other commemorative sites, including '60th Anniversary' (2009) on People's Daily Online, which is the official media voice of the $\mathrm{CCP}$, the website provides links to webpages that celebrate the history and combined achievements of the Party and 'the people' in realizing China today-a modern superpower. Unlike other sixtieth anniversary websites, it incorporates a celebrity section called 'Evolution of the Idol' ('Ouxiang jinhualun' 2009, hereafter Idol).

The Idol website presents a narrative describing the evolution of celebrity in the PRC as shaped by six decades of social change, and shifting along with China's post-1978 adoption of market-based economic reforms from the collective admiration of socialist heroes towards the alienated adoration of commercial celebrities. Idol subsequently calls on China's netizens to confirm or challenge this introductory and degenerative account of fame and fandom. Each generational decade of the PRC's sixty-year history is represented by a webpage containing a statement about the nature of idol worship during that period and images of selected idols. Visitors can click on each image to read 
biographical information and concluding statements about the idol's achievements. They can also click on a caption next to the image of each idol to register a vote for which public figure they most admire. Voters can select only one idol per decade, with the total number of votes updated daily. An associated statement tells readers that 'the power of examples is infinite; each generation of youths has their own idols' ('Zhuixun xiandai Zhongguo' 2009). It then enjoins visitors to post their age, the name of their idol, and to explain how that idol has influenced their lives.

A comparison of Idol voting figures and those amassed on other entertainment and anniversary websites demonstrates that Idol's 'idols' are more popular than might appear at first glance, given that Idol attracted only 62,474 votes by 21 October 2009 (see Appendix). Super Girls, a Chinese television Pop Idol competition, received 840 votes on Idol, whereas a search for the 2005 winner, Li Yuchun, on China's most popular search engine, Baidu.com, generates over seven million hits. Similarly, Lei Feng, a model soldier, received 6,426 votes on Idol, but obtained more than three million votes on a People's Daily anniversary website called 'China's Top "Double Hundred” Personages' ('Quanguo “shuangbai” pingxuan' 2009, hereafter 'China's Top 200'). Like Idol, China's Top 200 calls on visitors to vote for their idols. Unlike Idol, it focuses exclusively on the PRC's founding heroes and exemplary citizens, rather than including entertainers and famous people from China and around the globe.

This paper interrogates and contextualizes the Idol website as a means to provide a preliminary account of the evolution of different historical conceptions of fame and celebrity in the PRC, and associated constructions of 'modern China.' The Idol website is a useful starting point for understanding the evolution of conceptions of fame/celebrity in China for three reasons. First, in the absence of any definitive surveys or literature on the history of fame and celebrity in China from 1949 to 2009, it offers a cross-section of famous personages throughout the PRC's history that is as representative and inclusive as many other possible concise listings. This remains the case even though the suitability of the choice of famous individuals displayed on Idol is debatable, as it is decided unilaterally and possibly in an ad hoc fashion by anonymous website designers. Second, Idol's categorization of the PRC's history in terms of six generations offers broad insights into popular understandings of the values and aspirations of different groups of Chinese youth. I say 'broad' because referring to a 
generational decade as an homogeneous group with a common relationship to popular culture downplays the fact that young people experience different situations flowing from the specific social divisions and contexts associated with age, class, gender, ethnicity, sexuality, and urban and rural residency. Finally, Idol is a patriotic 'edutainment' website. Netizens 'searching' to understand modern China are enjoined to 'learn' that in contemporary China the historical experiences of the early PRC and the influences of global capitalism have converged to create a superpower that is driving the world economy and will help to shape the popular cultures of the future.

The next section briefly compares the narrative presented by the Idol website to popular models of the evolution of celebrity in contemporary media and cultural studies. The rest of the paper proceeds by charting, contextualizing and analyzing the website's stylized depiction of the evolution of celebrity in China on a chronological basis. The final section provides some concluding remarks.

\section{Comparing evolutions}

The history of idol worship in the PRC is portrayed in Idol's introductory narrative as shifting away from the collective admiration of socialist heroes of production towards the alienated adoration of commercial celebrities or idols of consumption (see Figure 1). In the 1950s, China's youth reportedly idolized heroes (yingxiong), as symbolized by an image of Huang Jiguang, a revolutionary martyr. In the 1960s, they idolized political role models (mofan), as illustrated by an image of Lei Feng, a model soldier. In the 1970s, they idolized symbolic role models (yangban), as represented by an image of Li Tiemei, a revolutionary-opera character. In the 1980s, they idolized famous people or stars (mingxing), epitomized by an image of Zhang Haidi, author and Chair of China's Disabled Persons' Federation. In the 1990s, they idolized disaffected youth (fenqing), as symbolized by an image of rock star, Cui Jian. Today, they idolize celebrities, ordinary people who have performed no exceptional deeds (bu jingying) but are simply 'famous for being famous,' as demonstrated by an image of Supergirl Li Yuchun.

The idea that idol worship has evolved in a degenerative fashion is neither new nor unique to China. Daniel Boorstin (1972: 6) provides a classic example of this position when he denounces contemporary celebrities on the grounds that: 'their chief claim to fame is their fame itself.' Comparing modern-day celebrities in the USA with former 


\section{Figure 1: Evolution of the Idol}

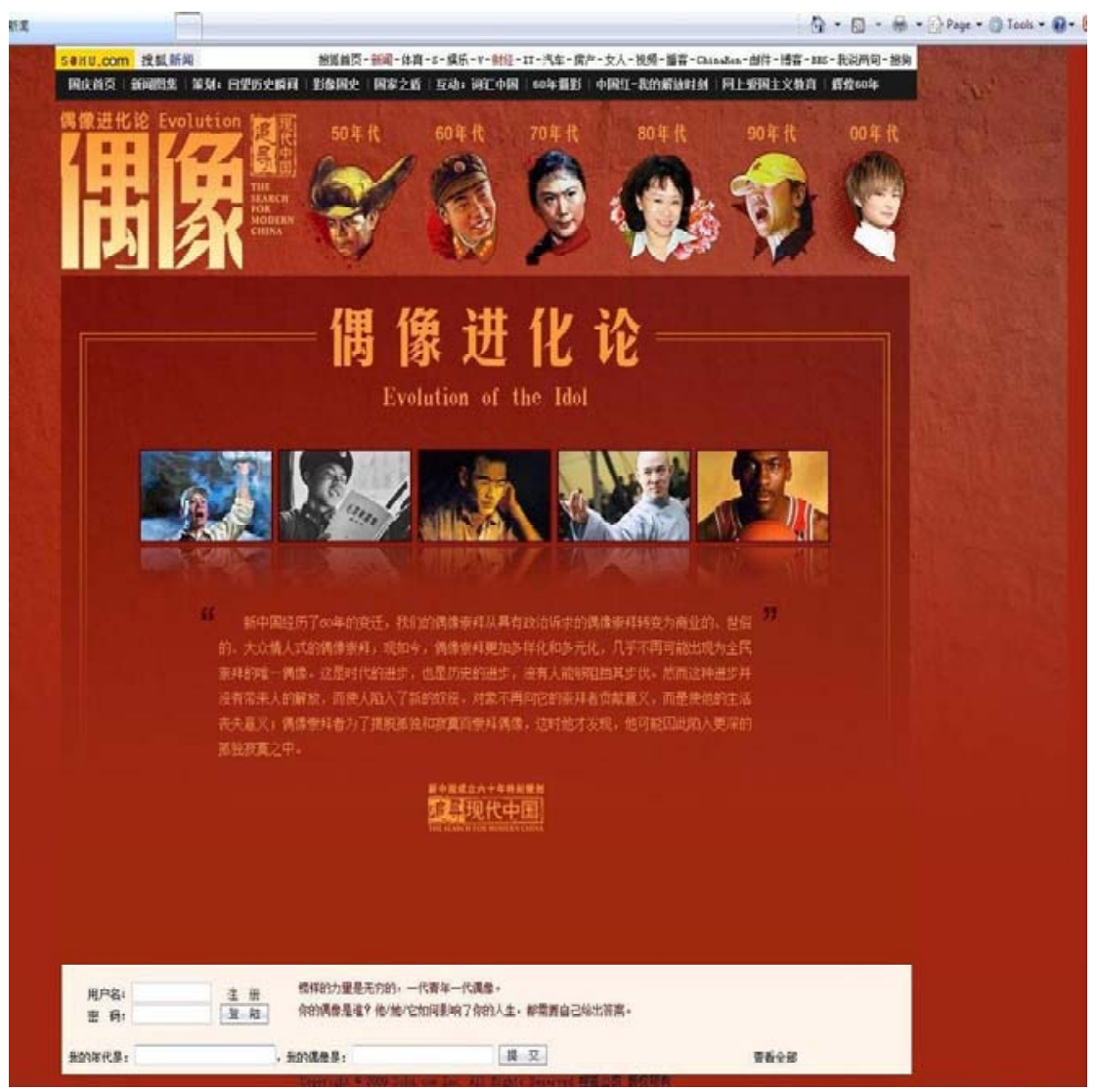

Screenshot (C) 'Ouxiang jinhualun’ 2009, Sohu.com

'heroes,' he concludes that 'The hero created himself; the celebrity is created by the media. The hero was a big man; the celebrity is a big name' (Boorstin 1972: 61). This style of argument implies that many contemporary celebrities deserve derision, not acclaim, because their fame is achieved primarily through media exposure and the media-fed trivia of lifestyle and personality, rather than through talent or great accomplishments (Redmond \& Holmes 2007: 8).

This negative conceptualization is intimately entwined with the history of celebrity in the USA, with the inventions of silent cinema (late nineteenth century), sound movies (the late 1920s), broadcast television (the 1940s), the Internet (the late 1970s), and social media (the 2000s), being key staging points or phase shifts in the narrative. The creation of 'talking' pictures ushered in a new age of movie stars, with an accompanying focus on the physical attributes and media-created persona of the star. Broadcast television intensified and extended this process by creating television stars and ultimately making 'ordinary' people temporarily famous via the proliferation of reality television programming and associated interactive formats in the late 1990s and 
early 2000s. Graeme Turner (2009) has coined the expression 'the demotic turn' to describe the increasing visibility of 'ordinary people in the media' and their apparent desire to celebritize themselves, via reality television shows, DIY websites, talk radio, and user-generated materials online.

The story told by the Idol website, while similar, differs in terms of the cultural and historical context which frames the narrative - the founding of 'New (socialist) China' in 1949 and the PRC's entry into the global economy after December 1978. Given that the early years of the PRC followed a period of intense violence, poverty, and famine, and the virtual elimination or impoverishment of the wealthy classes, the elevation through the state-controlled media of revolutionary heroes and martyrs (still living or not long dead) into popular youth idols is plausible, if not inevitable. The professed commitment of the socialist state to 'egalitarianism' also ensured that proletarian political role models were propagandized and popularized throughout the 1950s and 1960s. During the Great Proletarian Cultural Revolution (1966-1976), the emphasis placed on 'continuous revolution' guaranteed the reduction of state-controlled cultural production to 'politically correct' symbolic role models, although handwritten broadsheets, novels, poems, and other forms of popular cultural production also flourished. The narrative of the Idol website only converges with that of conventional western narratives from the 1980s onwards, with the expansion of commercial television, digital sound technology, and the Internet gradually generating popular cultural idols in the form of television and popular music stars, counter-cultural figures, writers and rock stars, and people who are 'known' for their 'well-knownness' (Boorstin 1972: 49, 57). Idol ultimately celebrates the PRC's sixtieth anniversary and attempts to appeal to youth audiences by refusing to condemn contemporary commercial celebrity per se, concluding that twenty-first century China has the capacity to manufacture celebrities that 'sell' both products and inspiration.

\section{Heroes}

The narrative presented by Idol begins with the victory of the Communist Party in 1949. That victory followed the end of the Second Sino-Japanese War (1937-1945) and decades of civil war between the CCP and the rival Nationalist Party. Freed from imperial oppression, and enjoying their hard-earned life as members of New China, people began to commemorate the deeds of those who had fought for its founding, 
especially those who had sacrificed their lives. After the Korean War (1950-1953), where Chinese 'volunteer' soldiers fought in aid of North Korea against the USA, they also commemorated those who fought against Cold-war aggressors. Hence, Idol states that China's youth of the 1950s idolized heroes, and images of war and struggle dominate the 1950s webpage (see Figure 2).

\section{Figure 2: The 1950s - Heroes}

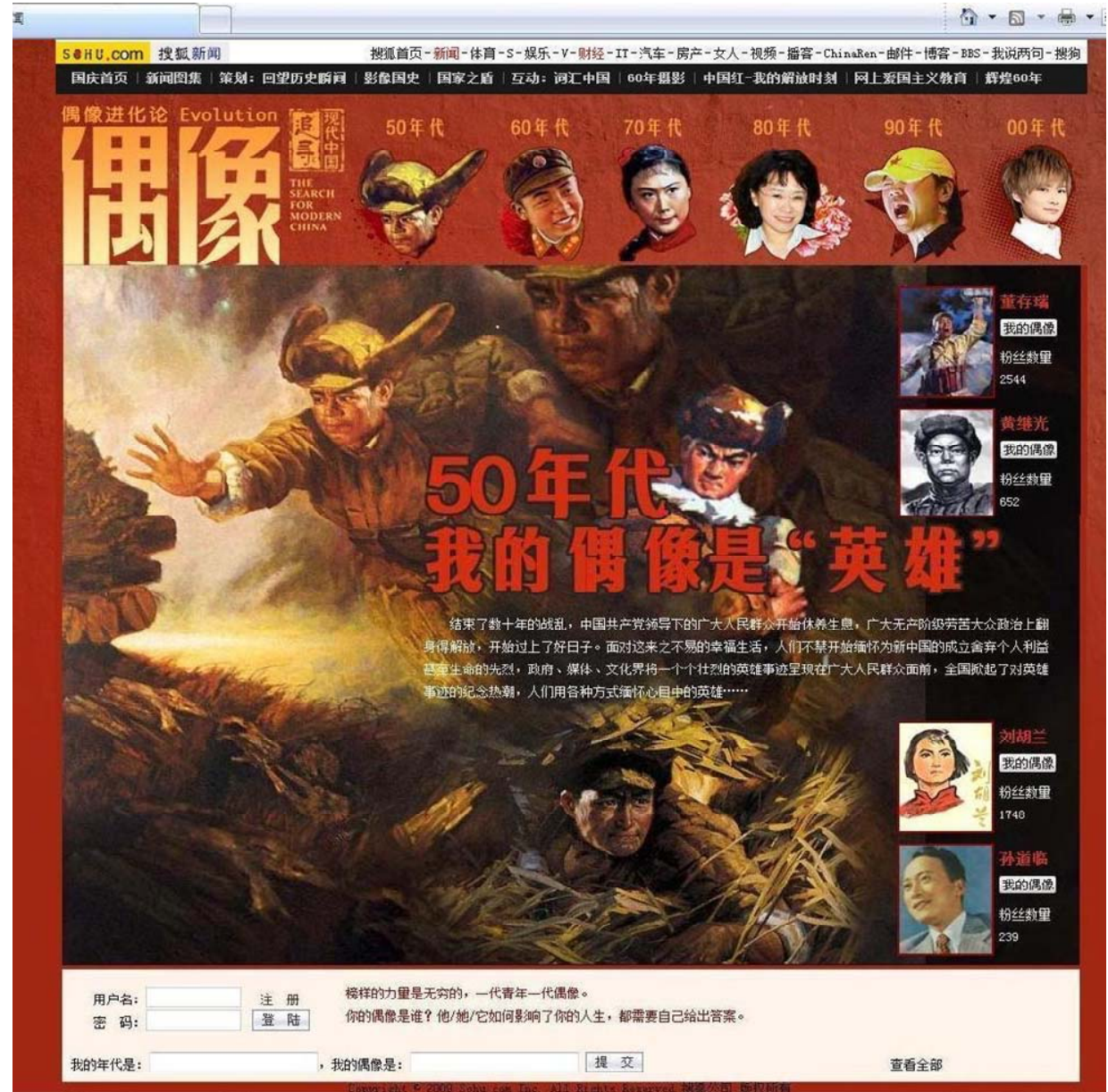

Screenshot (C) '50 niandai' 2009, Sohu.com

The four revolutionary heroes of the 1950s, displayed in descending order from the top right-hand to the bottom right-hand side of the webpage, are revolutionary martyrs Dong Cunrui (1929-1948), Huang Jiguang (1930-1952) and Liu Hulan (1932-1947)_ and film actor, Sun Daolin (1921-2007). Dong Cunrui (2009) is a hero from the Second Chinese Civil War (1945-1949). On 25 May 1948, the advance of Dong's unit of the People's Liberation Army (PLA) was blocked by a Nationalist bunker built on a bridge. The 19 year-old Dong volunteered to blow up the bridge, and, armed with a package of explosives, he ran towards the enemy lines, sustaining a broken leg from gunfire in the 
process. Unable to leave but realizing that his comrades had already begun their advance, Dong held up the explosives and lit the fuse. His sacrifice enabled the communists to take the bridge.

Idol underscores the remarkable nature of Dong Cunrui's heroism by referring to his slight stature and poor background; unlike conventional heroes whose accomplishments are, in part, a function of their privileged socio-economic status, he is a people's hero who had the courage to make the ultimate sacrifice because of his love of the CCP and the Chinese people. Dong features in a 1955 movie, re-released as a DVD in 2008. He was upheld as a national role model during a campaign to 'Learn from the PLA' in the mid-1960s. He is also commemorated via various statues and memorials and on a website celebrating the eightieth anniversary of the PLA in 2007 ('Dong Cunrui' n.d., 2007, 2008; 'Geming yingxiong dianying' 1955; Gittings 1964). Voted Idol's most popular hero of the 1950s, Dong received 58,315 votes on China's Top 200, demonstrating his longevity as a symbol of selfless service (see Appendix).

Liu Hulan $(2007,2009)$ is a female revolutionary martyr from the Chinese Civil War. Liu joined the Communist Children's Corps at the age of ten and later participated in training classes for rural women and mobilized her fellow villagers to support the CCP's military efforts and agrarian land reform. Nationalist Troops occupied her village on 12 January, 1947, confiscating the harvest and gathering the remaining villagers together. The Commander then asked a villager to expose communist sympathizers, which included the fifteen-year-old Liu. The Commander told Liu that he would spare her life if she named other sympathizers, but Liu refused and was decapitated with a sickle. Liu Hulan's posthumous, gendered celebrity as the youngest female member of the CCP to die for the revolution is confirmed by the more than half a million votes she received on China's Top 200 (see Appendix).

The heroism of Chinese servicemen during the Korean War is personified by the revolutionary martyr Huang Jiguang (n.d.; 2009). During the battle of Shangganling in October 1952, his unit attacked an enemy blockhouse. Injured and with the battle going against the Chinese soldiers, Huang threw himself against the machine-gun slit of a dugout manned by US troops, blocking enemy fire and forfeiting his life. His sacrifice enabled his comrades to win that battle, gaining him the posthumous award of 'SpecialClass Hero A feature film, Shang Ganling (1956) [Battle on Shangganling Mountain 
(2007)] was released in 1956 and re-released as a DVD in 2007. As with Dong Cunrui, Huang was promoted as a model for public emulation during a 1960s campaign to 'Learn from the PLA' and is honoured on the PLA's eightieth anniversary website.

Sun Daolin (2009) is not a 'real' hero, but rather is included on Idol as a film actor who inspired other people through his portrayal of revolutionary heroes, thereby highlighting a perceived disparity between meaningful stars and contemporary celebrities. As Idol explains, Sun Daolin found inspiration from the revolution and communicated that inspiration to the nation. His portrayals of revolutionary heroes made him a model of courage for countless young men. Likewise, his good looks and intelligence made him the 'dream lover' of many young women. As a university-educated man, his public performances further helped to unify the nation by blending the different masculine personas of 'the scholar' and 'the soldier.

In celebrating the revolutionary heroes of the 1950 s as authentic, Idol downplays the significant role played by the publicity/propaganda machinery of the newly formed Party-state in presenting 'real-life' individuals for public consumption as role models (Jeffreys \& Edwards 2010: 3). Throughout the Maoist period (1949-1976), China's citizens were offered a series of enhanced depictions of revolutionary heroes to emulate and learn from, by comparing their personal behaviours and thoughts with those of a preferred or prescribed idol and subsequently transforming their thoughts and behaviours in accordance with that role model. The use of nationwide mobilization campaigns to promote those models also meant that all children and adults were emulating the same hero at the same time (Sheridan 1968: 47).

In short, the CCP was a major creator of popular culture and youth icons at the time, (re)presenting revolutionary heroes for mediatized consumption to promote political cohesion rather than commercial goals. Idol's description of 1950s youth as a generation of young revolutionaries united in their admiration of authentic heroes is highly stylized; to the extent that this was true it was largely an effect of state control of the media and cultural production. Yet many of these idols have since been re-presented as emulation models via commemorative events and the distribution of feature films, as part of a campaign launched by the CCP in 1991, and expanded in 2004, to promote patriotic education by re-remembering the 'makers of the Chinese revolution' (Zheng 
2008: 794-97). Films and activities with patriotic content are promoted, especially during Chinese celebrations and holidays.

\section{Political models}

In the 1950,s and especially throughout the 1960s, the CCP began promoting a series of ordinary yet exceptional workers as political role models for young people to learn the spirit of the revolution and unify the nation. Such models embodied what it meant to be a good communist and imitating their personal example showed members of the public how to become one. Good communists were young people from poor backgrounds who, unafraid of hard work and adversity, selflessly served the Chinese people and the associated task of socialist development as best they could and in any manner that the $\mathrm{CCP}$ required. These models were promoted, along with the heroic 'makers of the revolution,' to create a new generation of 'revolutionary successors' for socialist China.

The Idol narrative consequently states that Chinese youth in the 1960s idolized political role models in the form of people who dedicated their lives to serving the people and national construction whole heartedly ('60 niandai' 2009). The top half of the webpage shows an image of three smiling children next to Lei Feng, a soldier renowned for his altruism (see Figure 3). Displayed from left to right across the bottom of the webpage, the five icons of the 1960s are Pavel Korchagin (literary Bolshevik hero); Shi Chuanxiang (1915-1975, model sanitation worker); Lei Feng (1940-1962, model soldier); Wang Jinxi (1923-1970, model industrial worker); and Jiao Yulu (1922-1964, model cadre).

Pavel Korchagin is the fictional hero of the socialist realist novel How the Steel is Tempered, by the Russian author Nikolai Ostrovsky (1904-1936). Despite experiencing extreme poverty as a child and later becoming blind and losing the use of his left arm and both legs from illness, Korchagin fought for the Bolsheviks during the Russian Civil War (1918-1921) and, after his illness, used the written word to inspire others to become good communists ('Baoer Kechajin' 2009). Korchagin, a teenager transformed into a resolute revolutionary or an 'iron man' in 'the crucible of war and revolution,' became a popular symbol of the Soviet 'new man' and a youth icon in early Maoist China (Cheng 2009: 34, 36). Chapters from the 'red classic' were translated into Chinese in 1937 and the entire text was translated in 1942, selling an estimated 2.07 
Figure 3: The 1960s - Political Models

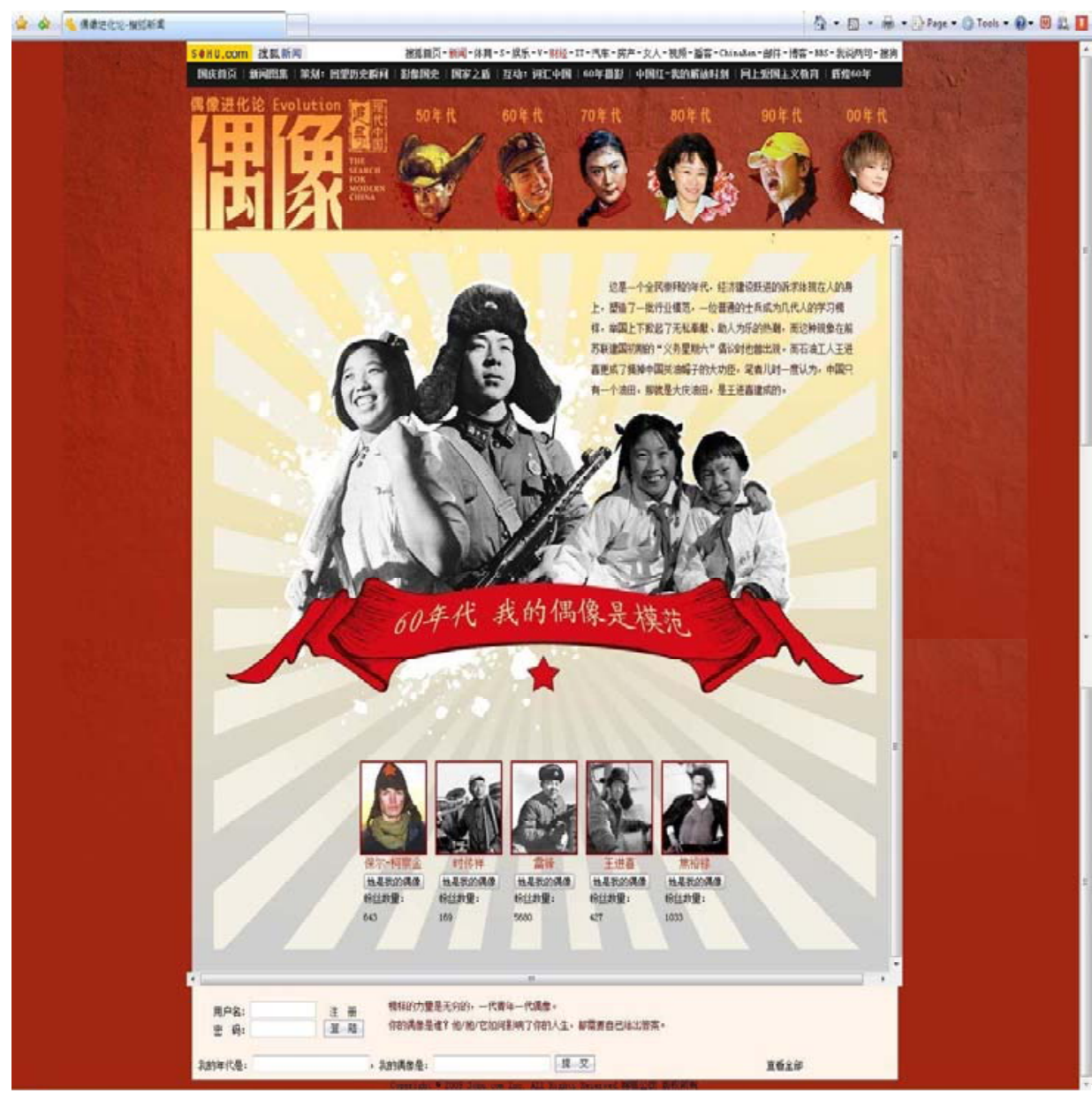

Screenshot (C) '60 niandai' 2009, Sohu.com

million copies by 1952 (Cheng 2009: 76). It inspired Wu Yunduo, a revolutionary war hero who sustained multiple injuries, including being blinded in one eye, to write a semi-autobiographical text, Totally Devoted to the Communist Party (ba yiqie xiangei dang), earning him the accolade of 'China's Nikolai Ostrovsky' (Cheng 2009: 36). How the Steel is Tempered is the subject of three feature films in the USSR and was adapted into a Chinese television series in 2000 ('How the Steel Was Tempered' 2009).

Lei Feng is a model soldier celebrated in China to this day for his willingness to serve the Party and people. An orphan, Lei died in an accident in 1962 aged twenty-two years. He achieved posthumous fame after his alleged diary was published in 1963, which celebrates Mao Zedong and the socialist ideals of altruism, and studying and working hard for collective goals (Edwards 2010: 26-30). As Idol explains, extensive promotion via the media and through collective activities has ensured that everyone in China is familiar with the Lei Feng Spirit of selfless public service ('Lei Feng, putong shibing' 
2009). These promotional activities include: Learn from Lei Feng campaigns; an annual

Lei Feng Day; cultural memorabilia in the form of t-shirts and shoulder bags; videogames; and a thirty-episode animation series, called 'The Story of Lei Feng,' which aired on China's Central Television Station on 1 June 2009 to coincide with International Children's Day ('Lei Feng' 2009; 'Lei Feng chuanren' n.d.; 'Lei Feng heritage' 2009). Voted Idol's most popular icon of the 1960s, Lei Feng's domestic celebrity is evidenced by the more than three million votes he received on China's Top 200 (see Appendix).

Shi Chuanxiang (2009) — a man 'who spent more than 40 years of his life shoveling and carrying manure from hole-in-the-ground public bathrooms' - is a model worker who allegedly championed the idea that 'one person gets dirty so that tens of thousands of people can stay clean' (Aiyar 2005). His story became compulsory primary-school reading after President Liu Shaoqi received him in 1959, and he became the subject of a feature film in 2008 ('Shi Chuanxiang' 2008). Idol concludes that Shi's willingness to work proudly for the Chinese people in a traditionally stigmatized job is an integral part of the PRC's 'spiritual' heritage.

Wang Jinxi (2009), China's first national role model in the industrial sector, is an oilfield worker renowned for his Iron Man Spirit—his inspirational courage to work hard in difficult circumstances to aid national development. Wang and his team drilled the first well of China's largest oil field in Daqing, while working in subzero temperatures without cranes and piped water, and they manually carried 60 tonnes of equipment from a railway to the field ('China's "Iron Man"' 2009). In 1960, Wang became the focus of a national campaign to 'Learn from the Iron Man' and he was made a labour model in 1967 (“'Iron Man” Wang Jinxi' 2009). He is the subject of a feature film called Iron Man (Tieren 2009), released on 1 May 2009 to coincide with international Labour Day. His life and actions are also commemorated in an Iron Man Memorial Museum that receives around 3,000 visitors a day ('China's "Iron Man"' 2009).

Jiao Yulu (2009a; 2009b) is a grassroots cadre who devoted his life to serving the Party and Chinese people. According to Idol, as Party secretary of Lankao County, Henan Province, Jiao worked ceaselessly to combat local environmental problems such as frequent waterlogging, sandstorms and soil salinization, until his death from liver cancer, a fact recalled with pride by his children in testimonials. In 1966, a campaign to 'Learn 
from Comrade Jiao Yulu: Good Student of Comrade Mao Zedong' was launched to rally people to work harder to overcome difficulties. Cadres were especially encouraged to follow Jiao's leadership style by investigating local conditions. In the early 1990s, Jiao became the subject of an award winning feature film ('Jiao Yulu' 1990). Voted Idol's second most popular icon of the 1960s, Jiao Yulu received nearly 800,000 votes on China's Top 200 (see Appendix).

As with the revolutionary heroes of the $1950 \mathrm{~s}$, many of the political models of the $1960 \mathrm{~s}$ are being re-remembered today via the creation of memory sites associated with the expansion of China's patriotic education campaign, such as websites, films, DVDs, video games, museums, historic monuments, sculptures and nostalgic memorabilia. However, the PRC's rejection of Maoist politics in the early 1980s has ensured that the production and consumption of such role models has become disconnected from the particular conception of revolution and national identity that they once embodied. Moreover, unlike the heroes of the 1950s who retain foundational importance for the PRC nation-state, the contemporary political relevance of idols of the 1960s has been undermined by their connection to a now-denigrated period in the CCP's history. With the exception of the odd television special, their presence in popular culture has mostly been reduced to circulating as niche market products for tourists in the form of revolutionary kitsch.

\section{Symbolic models}

The Cultural Revolution (1966-76) is denigrated in China today as '10 years of disaster,' and a period when the personality cult of Chairman Mao Zedong was used to incite (brainwash) China's youth into becoming revolutionary successors by attacking Party members who were accused of emphasizing material over ideological incentives, and thus taking the "capitalist road Reinforcing this emphasis on ideological conformity, the right-hand side of the Idol webpage for the 1970s is dominated by images of figures from the Legend of the Red Lantern (Hongdengji), one of the eight modern Beijing operas produced by Mao's wife Jiang Qing (see Figure 4). The operas aimed to inspire a new generation of revolutionaries by replacing traditional stories of emperors, generals, and concubines, with stories that celebrated the deeds of early Chinese communists, and were promoted extensively (some say ad nauseum) via state-sponsored music, theatre, film, and radio. Hence, Idol characterizes the early 1970s as a period when China's 
youth idolized 'symbolic role models' chiefly because they were provided with few alternatives, and describes the idols of that generation in collective terms as 'our idols' rather than 'my idol' ('70 niandai' 2009).

The 1970s webpage has two introductory notes that underscore the shift away from Maoist-style socialism towards the acceptance in December 1978 of Deng Xiaoping's market-based economic reforms and Open Door Policy ('70 niandai' 2009). As the first note explains, young people in the early 1970s admired the characters portrayed in the modern Beijing operas for epitomizing the revolutionary politics of class struggle (love and hate, struggle and self-sacrifice). However, the chaos and violence associated with the Cultural Revolution undermined support for this mode of revolutionary politics and continued class struggle. As the second note explains, young people in the late 1970s began to admire pioneers in literature and science, fields that had fallen into decline during the height of the Cultural Revolution, when schools and universities closed to allow students to engage in political activities. Separating these two notes, and displayed from left to right across the bottom of the left-hand side of the webpage, the four symbols of the 1970s are: Li Tiemei (fictional character, revolutionary-opera), Yang Zirong (1917-1947, combat hero, revolutionary-opera), Guo Lusheng (1948-, underground poet), and Chen Jingrun (1933-1996, mathematician) (see Figure 4).

Li Tiemei (2009) is a fictional character from the modern Beijing opera, the Legend of the Red Lantern. Adapted from the 1963 movie, the Revolution Has Successors (Geming ziyou houlairen), the opera tells the story of Li Tiemei and her father, a railway signaler who used his red lantern also as a device to communicate with communist guerrillas during the Second Sino-Japanese War. When her father is captured and executed by enemy soldiers, Li Tiemei accepts his last failed mission of smuggling information to communist forces, enabling an important victory and demonstrating her willingness to follow the family tradition of raising 'the red lantern' and risking her life for the revolution (Clark 2008: 35-6).

Yang Zirong (2009) is a combat hero from the Chinese Civil War whose ingenious actions are celebrated in the modern Beijing opera, Taking Tiger Mountain by Strategy (Zhiqu weihu shan). Adapted from a novel about Yang's life, the opera depicts a communist reconnaissance soldier who disguised himself as a bandit and used bandit 
Figure 4: 1970s - Symbolic Models

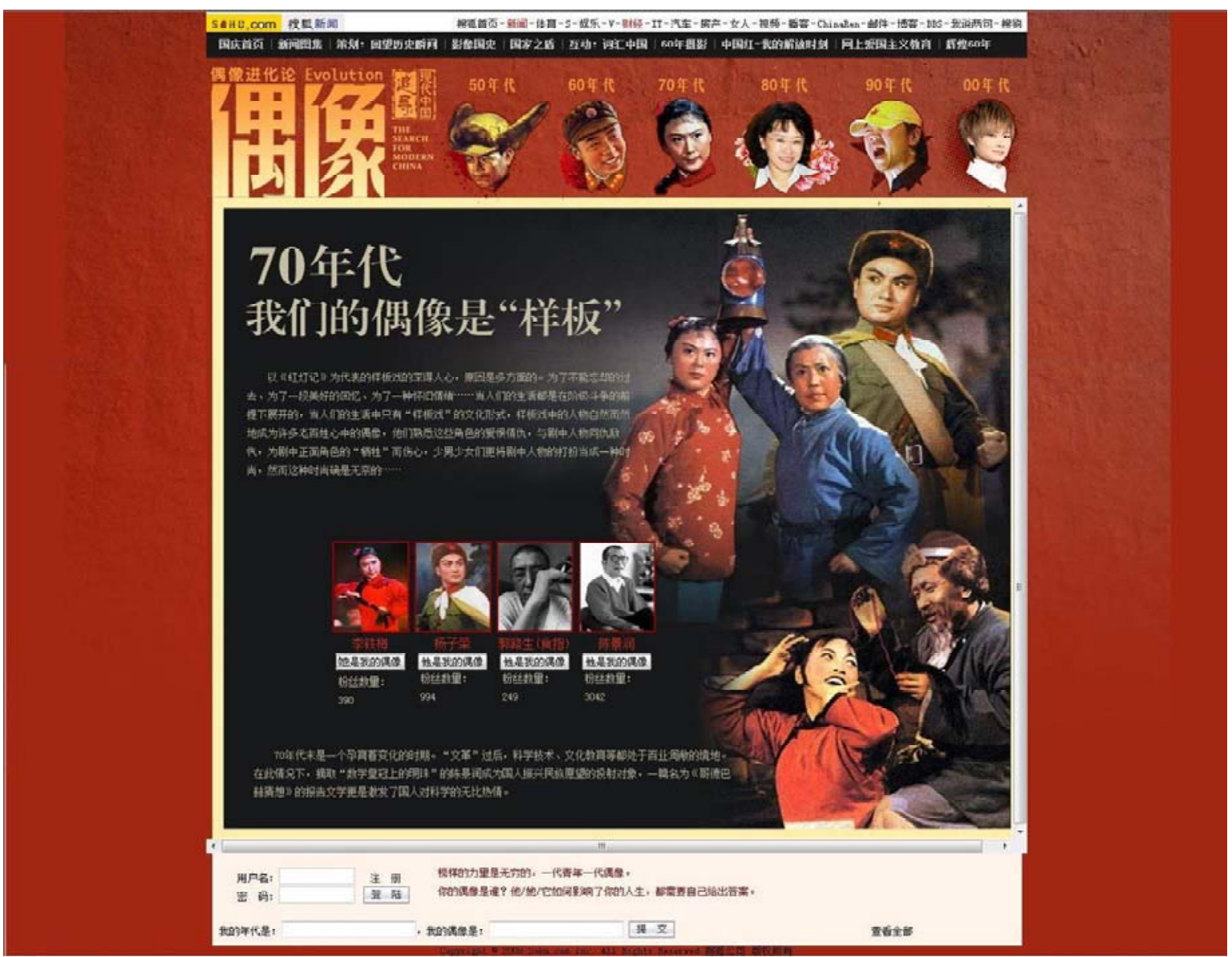

Screenshot (C) '70 niandai' 2009, Sohu.com

argot to infiltrate and capture a gang of bandits in 1947. Yang's life and actions were the subject of a 1970 feature film ('Zhiqu weihu shan'1970) and are now commemorated in a Yang Zirong Memorial ('Yang Zirong memorial commentary' 2008). Thousands of these memorials were created post-1994 as part of the patriotic education campaign and have become popular tourist destinations via the Red Tourism program, which was launched on a national scale by China's National Bureau of Tourism in 2004 (Zheng 2008: 797). Of the limited votes given to Idol's icons of the 1970s, Yang Zirong received the second highest and he is the only Idol icon from that era to feature on China's Top 200 (see Appendix).

Guo Lusheng or 'Shizhi' is an underground poet known as 'China's Dante' (Zhang 2002). Guo's poems were circulated unofficially during the Cultural Revolution through handwritten copies taken by some of the 17 million urban youth with a secondary or tertiary education who were 'sent down to the countryside'('Shizhi' 2009). Sent-down 
youth theoretically assisted with rural construction while learning from the peasantry. However, the relocation of urban youth to ease the pressures of urban unrest and unemployment became a source of resentment post-1968, because they often experienced not only personal deprivation, but also major difficulties in relocating back to the cities before 1981 ('Mixed memories of "Zhiqing"” 2004). As Idol puts it, Guo's 1968 poem 'Xiangxin weilai' (Trust the Future) captured the imagination of a generation of educated youth whose revolutionary idealism had been dampened by personal hardship and who wanted a different future (see also Davies 2007: 166-92).

Chen Jingrun, Idol's most popular icon of the 1970s (see Appendix), is one of the most famous mathematicians of the twentieth century due to his theorem 'on the representation of a large even integer as the sum of a prime and the product of at most two primes' (Chen's theorem) ('Chen Jingrun' n.d., 2009). Chen is celebrated on Idol in text and associated images for reviving the interest of China's youth in science and technology and solving one of the world's most famous mathematical problems while working in basic conditions-living in a small room and working on rough paper under the dim light of a kerosene lamp. He is thus portrayed as following in a tradition of people who were willing to overcome hardship to assist China's national development and pioneer a new path of scientific modernization.

The juxtaposition of revolutionary opera heroes and early pioneers of post-Maoist literature and science is symbolic of the striking shifts in Chinese politics and society that started to occur in the late 1970s. Guo Lusheng's and especially Chen Jingrun's fame represents the shift away from revolutionary politics, wherein scientists and other intellectuals were condemned as members of the 'stinking ninth category' who did not contribute to society, and towards the adoption of a model of national construction based on innovation and technological development. Through this example, Idol downplays the standard categorization of the youth of the Cultural Revolution as the 'lost generation' (shiluo de yidai). Instead, their loss of faith in Maoism, and desire for personal and national advancement, signifies China's newfound capacity to undertake the reforms required to become a superpower. While the selection of exemplars given by Idol is again very stylized, perhaps more important is the implicit assertion that the seeds of fundamental change in the nature of the PRC's role models lay in the political 
and popular turmoil of the 1970s, which would come to fruition as the Party-state's grip on the means of production was gradually relaxed in the reform period.

\section{Stars}

China's abandonment of revolutionary Maoism and entry into the global economy in the 1980s not only encouraged the formation of a new breed of famous domestic personages, but also introduced Chinese audiences to commercial popular culture from other parts of the world. As Idol explains through words emblazoned on a television screen to denote the creation and growing accessibility of commercial popular culture in the PRC, China's youth of the 1980s idolized a new generation of 'stars' (see Figure 5). Displayed from left to right across the bottom left-hand side of the webpage, the six stars of the 1980s are: Jet Li (1963-), martial arts master and film actor; Zhang Haidi (1955-), disabled role model; Sanmao (1943-1991), travel writer; Zhang Hua (19581982), controversial role model; Lai Ning (1974-1988), controversial child hero; and Michael Jackson (1958-2009), pop star.

Figure 5: 1980s - Stars

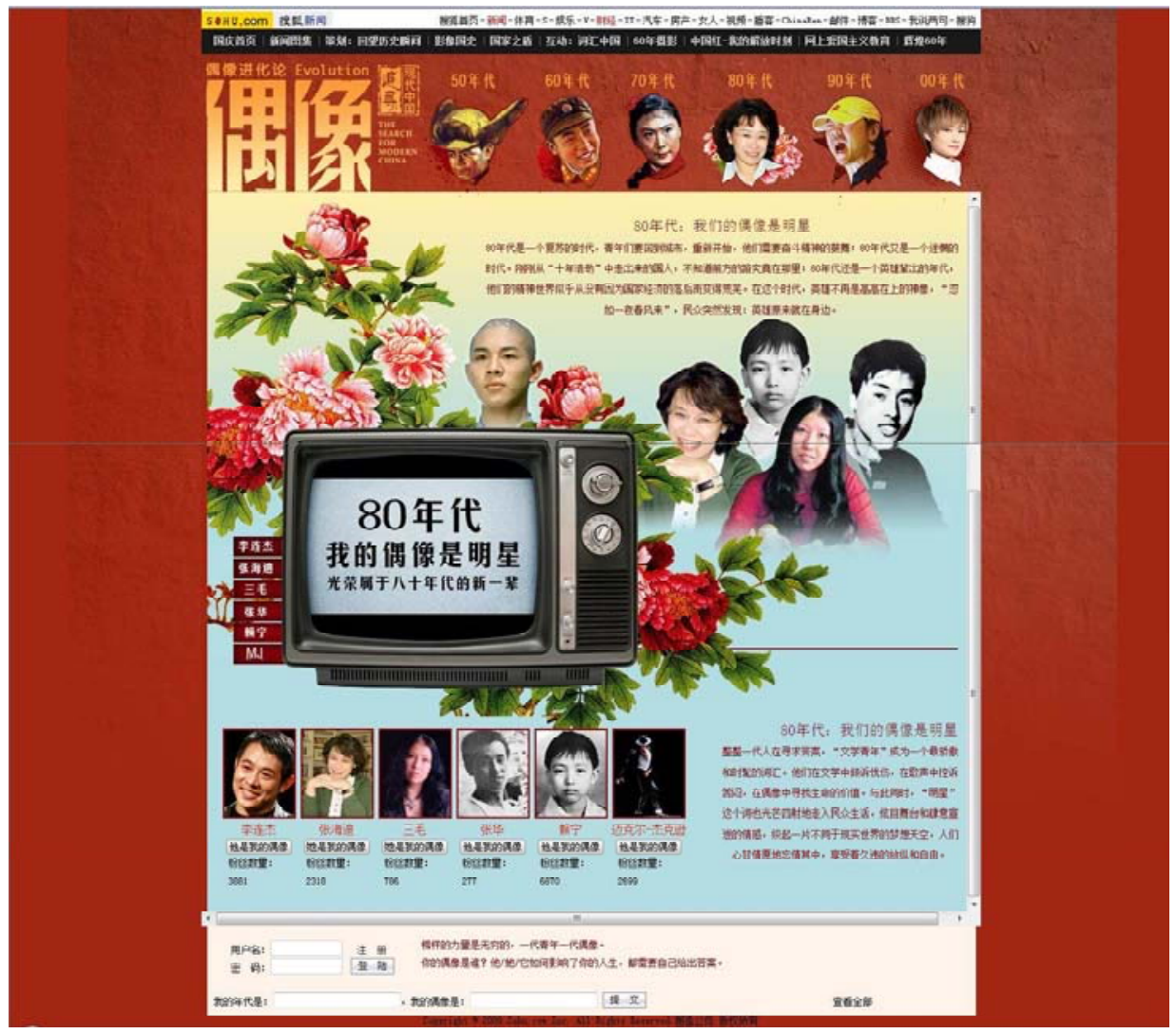

Screenshot (C) '80 niandai’ 2009, Sohu.com 
Zhang Haidi, Zhang Hua and Lai Ning are early reform-era role models, the controversy associated with both of them highlighting the continued production but diminished popularity of state-manufactured idols. Zhang Haidi (2009) contracted a spinal cord disease at five years of age that left her a paraplegic. Undaunted, she went on to complete undergraduate and masters degrees, and authored and translated numerous literary works. She also taught herself acupuncture, offering free medical services to over ten thousand people. In recognition of these services, President Hu Jintao called Zhang Haidi the 'Lei Feng of the 1980s.' A former member of the Chinese People's Political Consultative Conference, Zhang is married and promotes independent living for the physically challenged as Chair of China's Disabled Persons' Federation (Zhang Shun 2005).

Medical student Zhang Hua (n.d., 2009) died in 1982 aged twenty-four years after jumping into a septic pit to rescue an elderly peasant who had fallen in accidentally, with his posthumous promotion as a model of service and self-sacrifice attracting criticism. People questioned whether Zhang had really saved the old man, whether his sacrifice had any social utility, given that he would have saved more lives as a doctor, and whether he would have received official recognition if he had lived. Idol suggests that this questioning of socialist role models took place in a context of flux-China's youth were confused about the nature of appropriate behaviours and ideals, flowing from the PRC's entry into the global economy - and introduces testimonials from Zhang's colleagues to imply that such confusion was neither universal nor long-lived. Zhang Hua (2009) reportedly wished to join the CCP but had deferred temporarily, believing that he lacked the heroic qualities of a worthy member. Following Zhang's death, the Fourth Military University of Medical Sciences erected a bronze statue in his honour, at which first year students still swear a ceremonial oath to save lives.

Lai Ning died in 1988 aged 14 years fighting a forest fire and allegedly protecting state property: Lai and his classmates were ordered to help fight the fire. While not explicitly mentioned on Idol, the CCP launched a 'Learn from Lai Ning' campaign following the brutal suppression of the student protest movement in Tiananmen Square in June 1989, in order to offset the image of protesting students with other young role models ('Lai Ning' 2009a). Idol describes Lai Ning (2009b) via testimonials as a mischievous and awkward child transmogrified inappropriately into a fire-fighting hero, concluding that 
'forgetting him' is perhaps the best course of action because laws protecting minors, and governing schools, now forbid student involvement in rescue-style activities. However, Lai is Idol's most popular idol according to voting preferences and he received nearly 200,000 votes on China's Top 200 (see Appendix). This popularity reflects the fact that around 60 percent of China's netizens are under 30 years of age (China Internet Network Information Center 2010). Most Idol voters would have been born in the 1980s and educated about Lai Ning at school; moreover, they were prepared to engage with CCP-inspired versions of national solidarity, as demonstrated by their willingness to explore the anniversary website in the first place.

Jet Li, Sanmao and Michael Jackson represent China's gradual entry into the global economy and associated engagement with international popular culture. Voted the sixth most popular icon on Idol (see Appendix), Jet Li, a rag-to-riches international film star, was a national martial arts champion in the Maoist 1970s, representing the PRC at international athletic and cultural events, including performing on the White House lawn for President Nixon in 1974. He became a regional film star portraying warriorheroes in the early 1980s through the China-Hong Kong production, Shaolin Temple (dir. Zhang Xinyan 1982), and a global superstar in the 2000s via transnational films such as Hero (dir. Zhang Yimou 2002) (Farquhar 2010: 103-23). While intimating that Jet Li's popularity in China faded when he left (unpatriotically) for Hollywood in 1999, Idol concludes that Li has since salvaged his reputation by establishing the One Foundation, China's first independent public-funding raising charity (The Official Jet Li Website 2010; 'Li Lianjie' 2009).

Sanmao (author, pseudonym) was born in mainland China in 1943 but raised in Taiwan, making her a symbol of the political divide between communist China and nationalist Taiwan. She is famous both for her Chinese-language poetry and writings about travel and for her personal misfortune- - her German fiancée and subsequent Spanish husband both died tragically and she hanged herself in 1991 (Chen Shaohua 2007). According to Idol, Sanmao (2009) is remembered for her writings, life, and alleged yearning for home (China), as encapsulated in poems such as the 'Olive Tree,' which originally was prohibited in Taiwan for alluding to the PRC. Taiwan only began to allow individual travel abroad for tourism in 1979 and travel to mainland China for family reunification in 1987. Similarly, the opportunities for PRC citizens to obtain passports and travel 
overseas were highly restricted until the mid-1980s and remained limited throughout the 1990s because of cost and difficulties in obtaining visas (Liu, G. 2009). Sanmao's writings thus opened a window for PRC citizens into a little known outside world.

Idol's final icon of the 1980s is Michael Jackson, the 'King of Pop,' whose highly publicized death on 26 June 2009 presumably coincided with the website's construction. Allegedly more famous in China than Elvis or the Beatles, Idol describes Jackson as a cultural icon that everyone knows of even if they dislike his music and what he stands for ('Maike'er Jiekexun' 2009). Jackson's checkered history is used to imply a contrast between the PRC's tentative opening up to the outside world, scarred by global condemnation of the 1989 political crackdown, and its present-day status as a postBeijing Olympics superpower. Most notably, a quotation from Jackson reiterates for Chinese audiences the official representation of the 'Tiananmen Incident' as having been exaggerated by the international media to maintain China's former political and economic inferiority vis-à-vis the USA: 'They did everything they could to turn the public against me. It is a [media-led] conspiracy!' ('Maike'er Jiekexun' 2009).

Jackson also symbolizes China's Generation Y, an estimated 240 million people born between 1981 and 1995 whom Idol describes as destined for glory by leading China's modernization ('80 niandai' 2009). Generation Y is typically contrasted with the Cultural Revolution generation because of its newfound optimism for the future, and active engagement in entrepreneurship, consumerism and popular culture. Jackson's epitaph on Idol - a superstar who shook the world and whose death signifies the end of an era-is thus a metaphor for the death of 'old' New China and the rise of new millennium China.

\section{Disaffected youth}

In the 1990s, China's growing integration with the global economy, the emergence of self-made entrepreneurs (the newly rich), the return of Hong Kong to Chinese sovereignty in 1997, and expanded cultural exchange between the PRC and Taiwan, encouraged a shift away from the state-led emphasis on entertainment as education and towards commercial entertainment for entertainment's sake. Hence, Idol states that Chinese youth in the more liberal political climate of the 1990s idolized 'disaffected youth' for their countercultural questioning of former communist orthodoxy (' 90 niandai' 2009). Displayed from left to right across the bottom of the webpage, the nine 
icons of the 1990s are: Xiaohudui [Little Tigers], Taiwanese boy band; Cui Jian (1961-), Chinese rock star; Luo Dayou (1954-), Taiwanese singer-songwriter; Wang Shuo (1958-), Chinese author and television producer; Stephen Chow (1962-), Hong Kong film director; Liu Huifang, PRC soap-opera character; Bill Gates (1955-), entrepreneur, USA; Michael Jordan (1963-), basketball player, USA; and Mary Kay Ash (19182001), entrepreneur, USA (see Figure 6).

Figure 6: 1990s - Disaffected Youth

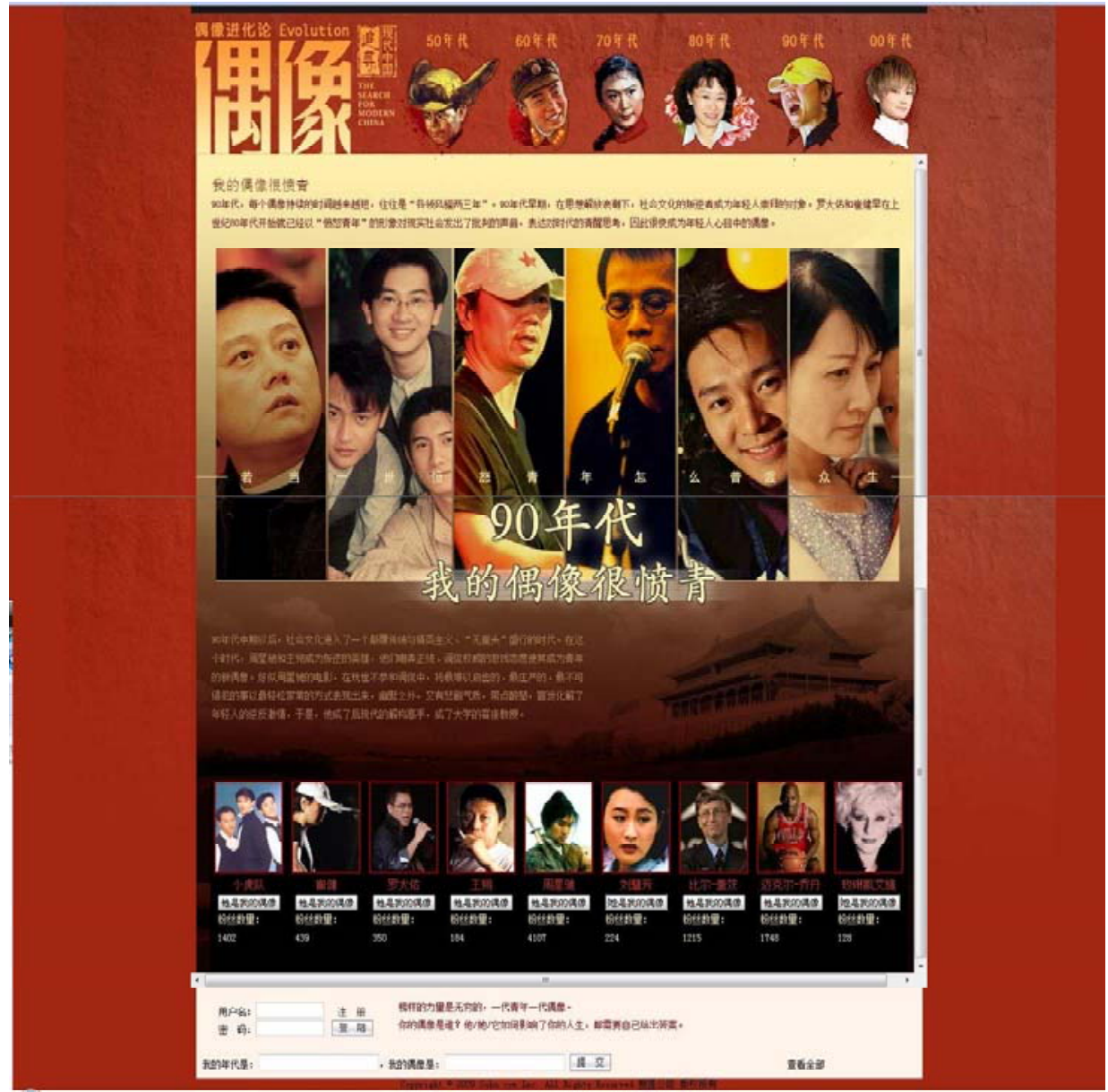

Screenshot (C ‘90 niandai’ 2009, Sohu.com

Xiaohudui, Cui Jian and Luo Dayou epitomize the changing face of Chinese popular music and the alternative 'voice' of a new generation. Taiwanese boy-band, Xiaohudui (2009) were Asian pop idols from 1988 until the band split up in 1995. Cui Jian (2009), often dubbed the 'father of Chinese rock,' is renowned as a countercultural voice of idealism and discontent. He shot to fame in the late 1980s when his song 'Nothing to My Name' (Yiwusuoyou), an implied criticism of the claim that socialism provides a better quality of spiritual and material life, became an anthem to student protestors in 
Tiananmen Square (Hom 1998: 1013). Luo Dayou (2009), the 'godfather of Chinese popular music,' is a Taiwanese (folk) singer-songwriter. These idols represent the influence of commercial music from western societies, Hong Kong and Taiwan on mainland China. This influence was praised and condemned for introducing new (raucous) sounds and a focus on the personal, rather than the CCP-led cultural emphasis on asceticism and socialist modernization (Gold 1993); for example, love songs containing what were viewed at the time as sexually explicit lyrics (Moskowitz 2009: 69-70).

Wang Shuo, Stephen Chow and the soap opera Kewang (Yearnings) represent the expansion of commercial literature, film and television programming in 1990s China. Contrary to the emphasis of state-funded writers on 'educating the masses,' Wang Shuo is a self-described 'literary entrepreneur' concerned with entertainment and sales, not morals or politics (Kong 2010: 131-36). Wang made his fame and fortune by publishing stories and novellas, many of which were adapted for film and television, about street-wise antiheroes whose playful use of colloquial dialect highlighted the disjunction between China's revolutionary past and the newly commercialized present, and mocked the former as 'not cool' (Barme 1992). While praising Wang Shuo (2009), Idol concludes that Wang Xiaobo (1952-1997), a satirical writer who eschewed (USstyle) literary commercialism, is more 'authentically creative.'

Idol similarly celebrates Stephen Chow as a comic genius, while concluding that 'inexperienced youth' should be wary of idolizing his cynical blending of tradition and innovation because it may result in confusion and depression ('Zhou Xingchi' 2009). An A-list Hong Kong actor, comedian, screenwriter, and film director, Chow is famous for his slapstick parodying of martial arts and other aspects of Chinese culture. Chow's movies Shaolin Soccer (2001) and Kung Fu Hustle (2004) both made history as the highest grossing films in Hong Kong.

Liu Huifang is the central female character in China's first domestically produced soap opera, Kewang, which broadcast in October 1990, attracting a record audience of 550 million people (Wang et al. 1992: 177-92). The 50-episode series followed the stories of several ordinary families from the Cultural Revolution period into the early 1980s, foregrounding issues relating to family relationships, class conflict, gender, and social morality. Its popularity stemmed in part from unprecedented media coverage. In 1980, 
there were 5 million television sets in the PRC; by the start of the 1990 s there were 160 million (Wang et al. 1992: 181). China's print media extensively debated the show in columns on 'What have I learnt from Kewang?' As Idol concludes, Kewang struck a chord with the entire nation. Faced with the social and moral ambiguities introduced by the market economy and western culture, it presented a newly nostalgic portrait of a time when human relationships purportedly were more innocent and based on 'Chinese values' of care and community ('Liu Huifang' 2009).

Bill Gates, Michael Jordan and Mary Kay Ash represent China's embrace of the global market economy, especially entrepreneurialism, commercial sports and cosmetic beautification. These areas were restricted or simply did not exist in Maoist Chinaindustry was nationalized and the monetary economy was curtailed, sport was funded by the state to demonstrate national strength, and the ideal revolutionary beauty was an asexual and naturally rosy-cheeked (peasant) worker. Idol celebrates Bill Gates for cofounding Microsoft and becoming one of the richest people in world history, thereby changing the way people live, work and communicate, and inspiring a new generation of self-made Chinese entrepreneurs ('Bier gaici' 2009). Michael Jordon is celebrated as a model of success in sport and commercial sports advertising and for introducing China's youth to basketball, the most famous and unmentioned of which is Yao Ming ('Maike'er qiaodan' 2009). Finally, Idol celebrates the founder of Mary Kay Cosmetics, which opened a China subsidiary in 1995, under the heading 'spreading the rebirth of feminism,' as a successful female entrepreneur in the context of China's changing views about feminine beauty and sexual liberation ('Meilinkai aishi' 2009). The PRC is now the eighth largest cosmetics consumer in the world ("Chinese Women Go "Crazy" for Cosmetics' 2005). As in other societies, China's 'fashion revolution' is both praised for introducing heterogeneity and individual freedoms and condemned for turning women into sex objects.

In short, the spread of entrepreneurialism and commercial popular culture, incorporating new influences from Hong Kong, Taiwan, and 'the West,' further loosened Party-state control of the economy, media and everyday life and brought a new dynamism to the mainland economy and cultural market. At the same time, the belated entry of the PRC into the global economy placed China as an imagined centre of civilization in a peripheral position both regionally and globally. The 1990s thus also represent a time 
when concerns about China's future and how China's past might contribute to a better (as in non-western) imagining of that future began to emerge.

\section{Celebrities}

As with degenerative accounts of the evolution of celebrity in western societies, Idol notes that older members of Chinese society, in particular, view the 2000s as an era dominated by commercial celebrities and consequently as an era without true idols and ideals ('00 niandai' 2009). While bemoaning the death of 'real' heroes, Idol attempts to appeal to youth audiences by concluding that the longevity of contemporary idols and what they stand for is uncertain; it is up to the youth of China today to provide the answers and hence to define the nature of modern China. Displayed from left to right across the bottom of the webpage, the six icons of the 2000s are: Meteor Garden (Liuxing huayuan), Taiwanese teen drama; Jay Chou (1979-), Taiwanese pop idol; Big Big Wolf, Chinese cartoon character; Super Girls, Chinese Pop Idol competition; Harry Potter, fictional adolescent wizard; and, Xu Sanduo, the central character in a Chinese television drama (see Figure 7).

Figure 7: 2000s - Celebrities

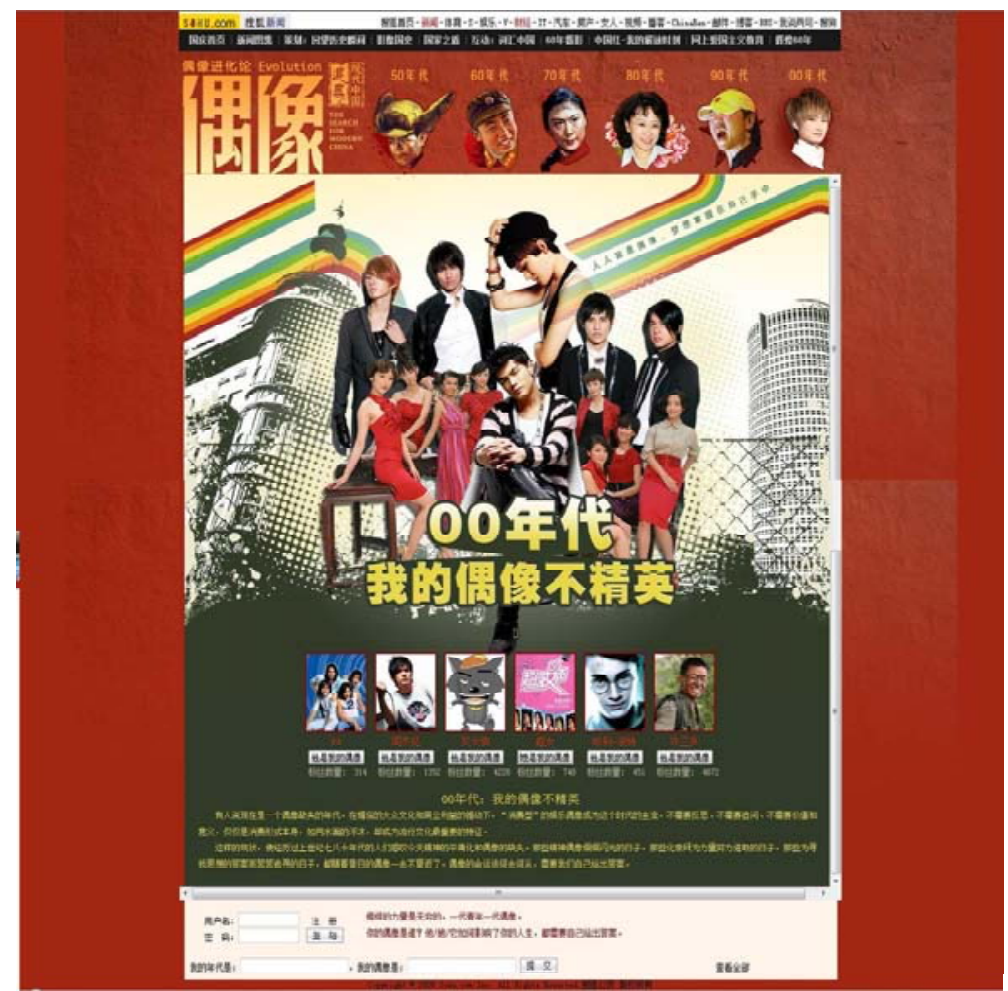

Screenshot ( $\odot$ '00 niandai’ 2009, Sohu.com 
While Harry Potter (2009) is included into the pantheon as a global phenomenon highlighting the cosmopolitanism of contemporary Chinese youth, Meteor Garden, Jay Chou and Super Girls represent the emergence in 2000s China of teen-orientated entertainment and a corollary shift away from venerating heroes towards idolizing highly commoditized performers who are usually young, good-looking and may possess little or no talent. Meteor Garden, a Taiwanese TV drama based on a 'live' version of the Japanese manga, Hana Yori Dango (The Boys More Than Flowers), was first broadcast in April 2001. Its popularity throughout Asia resulted in two sequels, Meteor Rain and Meteor Garden II. The show revolves around four rich and popular boys at an elite college (F4), who gradually gain in wisdom and maturity through facing romantic and other crises ('Liuxing huayuan' 2009). Meteor Garden became popular in the PRC via the medium of DVDs, with F4's transformation into East Asia's hottest 'boy-band' at the time resulting in sold-out concerts in China being cancelled due to hysterical crowds (Huat 2004: 210).

Jay Chou and Supergirls embody the new Chinese teenage fantasy of ordinary but talented youths being 'discovered' and transformed into megastars ('Zhou Jielin' 2009). A Taiwanese musician, singer-songwriter and actor, Chou came to public attention after winning a talent show in 1998 at the age of nineteen ('Zhou Jielin' 2009). He has won at least three World Music Awards for his Chinese-Western fusion of jazz-influenced rhythm and blues, pop and hip hop, with song lyrics in Mandarin (Moskowitz 2009: 72).

Super Girls was a hugely popular national singing contest for 18 to 20 -year-old female contestants organized on an annual basis by Hunan Satellite Television between 2004 and 2006, around 80,000 pop 'wannabes' auditioned for the show in 2006 and 280 million people watched the final heat ('Footage from banned Chinese "Pop Idol"' 2007). Idol celebrates Super Girls as a cultural phenomenon that not only demonstrates China's capacity to create its own idols, but also provided ordinary young women with ultrasuccessful role models, such as 2005 winner, Li Yuchun, named by Time Magazine as one of Asia's heroes ('Chaoji nüsheng' 2009; Jakes 2005). Commentary by cultural critics variously praise the show for marking the rise of youth popular culture and the defeat of elite culture in China; and, since winners were elected by SMS voting, for helping to create an active citizenry. However, Idol concludes that the popularity of 
Super Girls ultimately stems from successful business marketing, implying that the talent of the show's winners is inauthentic and an over-rated product of media hype.

Huitailang [Big Big Wolf] represents the PRC's policy goal as expressed by the Ministry of Culture of achieving international animation status by around 2015 ('Huitailang' 2009; Li Qiaoyi 2009). Big Big Wolf is a central character in Xiyangyang he huitailang (Pleasant Goat and Big Big Wolf), a Chinese 3D cartoon animation film and box-office success based on a cartoon series of the same name. The relatively lowbudget film by Shanghai Media Group is the largest grossing Chinese feature animation, beating DreamWorks' Madagascar 2 (dir. Darnell \& McGrath 2008) and Disney’s Bolt (dir. Williams \& Howard 2008) at China's box offices in 2009 (Song Hongmei 2009). Big Big Wolf is reportedly popular because he represents an ideal man from a Chinese woman's perspective. Born a wolf and thus unfortunately having a wolf's nature, he is also a smart, capable, loving, uncritical, and loyal husband who cooks.

The narrative presented by Idol concludes with 'Xu Sanduo' (2009) - the central character in a Chinese television drama titled Soldiers Sortie (Shibing tuji), and voted Idol's third most popular figure after Lai Ning and Lei Feng (see Appendix). The show's plotline is simple: Xu's father forces him to join the army, viewing him as a cowardly dullard in need of military training. While experiencing numerous ritual humiliations during rigorous training, $\mathrm{Xu}$ makes close friends, finds himself and becomes an outstanding soldier. Soldiers Sortie was broadcast with low ratings in December 2006, but developed a cult following in 2007 as 30,000 DVDs went on sale and 'soldier fans' began posting commentaries about the show on Baidu.com. Fanbased Internet surveys suggest that the show's audience comprises people from all walks-of-life and age groups, although 20 to 30 year old viewers comprise the largest audience. Men reportedly 'love it' because they see the protagonists as 'true men'; and women 'love it' because they see them as 'ideal men' (Zhang Ming'ai 2007).

The evolution over the PRC's history from idolizing 'real' soldier-heroes to worshipping fictional ones is intended to highlight the cosmopolitan yet unique nature of contemporary Chinese youth. Attributing the popularity of Soldiers Sortie to the 'hunger' of Chinese youth for spiritual role models, Idol suggests that Xu Sanduo's unexceptional nature - his honesty, lack of sophistication and perseverance-is exceptional (as is China). It reminds young people, who are living in an era of overt 
materialism, and perceived moral decline, that financial success is not the sum total of human existence. Successful people have a sound moral character and are content with their lives and at peace with others. In short, modern China can create celebrities that 'sell' both products and inspiration to a new generation of aspiring young people and future (world) leaders.

\section{Conclusion}

The history of celebrity and idol production in the PRC can be viewed crudely as marked by disjuncture: the decline of heavy-handed Party-state involvement in the propagandistic manufacturing of socialist idols of production, followed by the graftedon rise of western-style media-manufactured celebrities as idols of capitalist consumption. This framing narrative informs the selective collection and categorization of idols presented on the 'Evolution of the Idol' component of 'The Search for Modern China' anniversary website. Idol presents a degenerative account of Chinese popular culture and idol worship as shifting somewhere between the mid-1970s and 1980s from the production and veneration of authentic heroes to the production and idolization of consumer-style celebrities, following the gradual discarding of Maoist principles and adoption of market-based economic reforms. At the same time, Idol somewhat glibly concludes that the associated decline in the reform era of social(ist) values and the rise of individualistic materialism presents neither a serious nor ongoing problem, because the recent creation of inspirational celebrity-commodities shows that China is capable of reinventing the past to serve different present and future needs.

More interestingly, perhaps, analyzing the Idol pantheon highlights the diversity of China's celebrity-constructions and the continued vitality of state-produced socialist icons in commercial popular culture. Although some idols from the Maoist and early reform period have been relegated to the realms of fiction or, revolutionary kitsch, or are now simply passé, the state-led project of promoting patriotic education by reremembering selected 'makers of the Chinese revolution' has ensured that others remain very much alive in the popular imagination via contemporary memory sites associated with broadcast television, DVDs and the internet, and the historical locations, museums and monuments of 'red tourism Revolutionary heroes, for example, are a nightly presence in films, documentaries and dramas shown on contemporary Chinese television, juxtaposed beside variety and reality shows featuring popular entertainment 
stars of the 2000s and celebrity news. As advertising for a celebrity-hosted 'Lei Feng Day' marathon on Beijing Television Station on 5 March 2012 put it: 'Lei Feng was and always will be with us' (Lei Feng yizhi zai women shenbian).

\section{Acknowledgements}

The Australian Research Council supported this research. 


\begin{tabular}{|c|c|c|}
\hline \multicolumn{3}{|c|}{ Appendix: Voting Patterns on Anniversary Websites ${ }^{\dagger}$} \\
\hline & Idol* & People’s Daily** \\
\hline \multicolumn{3}{|l|}{ 1950s - Heroes } \\
\hline Dong Cunrui $\hat{o}$ & 2,885 & 58,315 \\
\hline Huang Jiguang $\widehat{\jmath}$ & 779 & 26,760 \\
\hline Liu Hulan $q$ & 1,906 & 508,883 \\
\hline Sun Daolin $\sigma^{\top}$ & 292 & 51,374 \\
\hline \multicolumn{3}{|c|}{ 1960s - Political Models } \\
\hline Pavel Korgachin ${ }_{0}^{\pi}$ & 740 & - \\
\hline Shi Chuanxiang $\widehat{\partial}$ & 202 & 6,460 \\
\hline Lei Feng 0 & 6,427 & $3,375,400$ \\
\hline Wang Jingxi $\widehat{\partial}$ & 537 & 28,974 \\
\hline Jiao Yulu ${ }^{\lambda}$ & 1,238 & 773,257 \\
\hline \multicolumn{3}{|c|}{ 1970s - Symbolic Models } \\
\hline Li Tiemei 9 & 447 & - \\
\hline Yang Zirong ổ & 1,138 & 16,172 \\
\hline Guo Lusheng $\widehat{\partial}$ & 296 & - \\
\hline Chen Jingrun $\hat{\sigma}$ & 3,497 & - \\
\hline \multicolumn{3}{|l|}{ 1980s - Stars } \\
\hline Jet $\mathrm{Li} \precsim$ & 4,197 & - \\
\hline Zhang Haidi $q$ & 2,515 & 7,414 \\
\hline Sanmao $q$ & 871 & - \\
\hline Zhang Hua $\widehat{\sigma}$ & 317 & 18,443 \\
\hline Lai Ning $\widehat{0}$ & 7,304 & 195,812 \\
\hline Michael Jackson đ̊ & 3,394 & - \\
\hline \multicolumn{3}{|c|}{ 1990s - Disaffected Youth } \\
\hline Little Tigers $\widehat{\jmath}$ & 1,635 & - \\
\hline Cui Jian $\widehat{\partial}$ & 547 & - \\
\hline Luo Dayou $\widehat{\sigma}$ & 426 & - \\
\hline Wang Shuo $\hat{O}$ & 227 & - \\
\hline Zhou Xingchi §̊ & 4,580 & - \\
\hline Kewang & 299 & - \\
\hline Bill Gates $\widehat{o}$ & 1,400 & - \\
\hline Michael Jordan $\widehat{\partial}$ & 1,991 & - \\
\hline Mary Kay Ash ${ }_{+}$ & 154 & - \\
\hline \multicolumn{3}{|l|}{ 2000s - Celebrities } \\
\hline $\mathrm{F} 4 \hat{\jmath}$ & 365 & - \\
\hline Jay Chou $\sigma^{\top}$ & 1,538 & - \\
\hline Big Big Wolf $\jmath^{\lambda}$ & 4,794 & - \\
\hline Super Girls ${ }_{+}$ & 840 & - \\
\hline Harry Potter $\hat{O}$ & 510 & - \\
\hline Xu Sanduo $\sigma^{\lambda}$ & 5,186 & - \\
\hline
\end{tabular}




\section{Reference List}

'00 niandai: wo de ouxiang bu jingying' [The 2000s: My Idols Are 'Celebrities'] 2009, Ouxiang Jinhualun: Zhuixun Xiandai Zhongguo [Evolution of the Idol: The Search for Modern China], Sohu.com (hereafter Ouxiang). Online, available: http://news.sohu.com/s2009/9616/s266391777_1/ [accessed 8 February 2012].

'50 niandai: wo de ouxiang shi “yingxiong"” [The 1950s: My Idols Are 'Heroes'] 2009, Ouxiang. Online, available: http://news.sohu.com/s2009/9616/s266391504_1/ [accessed 8 February 2012].

‘60 niandai: wo de ouxiang shi mofan' [The 1960s: My Idols Are (Political) Role Models] 2009, Ouxiang. Online, available: http://news.sohu.com/s2009/9616/s266391505_1/ [accessed 8 February 2012].

‘60th Anniversary: People’s Republic of China’ 2009, People’s Daily Online. Online, available: http://english.peopledaily.com.cn/90002/97623/index.html [accessed 8 February 2012].

"70 niandai: women de ouxiang shi "yangban"” [The 1970s: Our Idols Are '(Symbolic) Role Models'] 2009, Ouxiang. Online, available: http://news.sohu.com/s2009/9616/s266391506_1/ [accessed 8 February 2012].

'80 niandai: wo de ouxiang shi mingxing, guangrong shuyu bashi niandai de xin yi bei' [The 1980s: My Idols Are Famous Stars, the Glory Belongs To the New Generation Of the 1980s] 2009, Ouxiang. Online, available: http://news.sohu.com/s2009/9616/s266391507_1/ [accessed 8 February 2012].

'90 niandai: wo de ouxiang hen fenqing' [The 1990s: My Idols Are Disaffected Youth] 2009, Ouxiang. Online, available: http://news.sohu.com/s2009/9616/s266391508_1/ [accessed 8 February 2012].

Aiyar, P. 2005, 'Gandhian China, Feudal India,' The Indian Express. 11 August. Online, available: http://www.indianexpress.com/oldStory/76027/ [accessed 1 June 2011].

Barme, G. 1992, 'Wang Shuo and Liumang (“Hooligan”) Culture,' The Australian Journal for Chinese Affairs, vol. 28: 23-64.

Battle on Shangganling Mountain 2007, Dir. Meng Sha, China: Qilu Audio and Video Press.

'Bier gaici' [Bill Gates] 2009, Ouxiang. Online, available: http://news.sohu.com/s2009/9616/s266486583/ [accessed 8 February 2012].

Boorstin, D. 1972 [1961], The Image: A Guide to Pseudo-Events in America. New York: Atheneum.

'Chaoji nüsheng' [Super Girls] 2009, Ouxiang. Online, available: http://news.sohu.com/s2009/9616/s266489264/ [accessed 8 February 2012].

'Chen Jingrun' n.d., Planetmath.org. Online, available: http://planetmath.org/encyclopedia/ChenJingRun2.html [accessed 1 June 2011].

'Chen Jingrun' 2009, Ouxiang. Online, available: http://news.sohu.com/s2009/9616/s266376869/ [accessed 8 February 2012].

Chen Shaohua 2007, 'San Mao-Taiwan's Wandering Writer,' All-China Women's Federation. 30 Nov. Online, available: http://www.womenofchina.cn/html/report/88989-1.htm [accessed 8 February 2012].

Cheng, Y. 2009, Creating the 'New Man': From Enlightenment Ideals to Socialist Realities. Honolulu: University of Hawaii Press.

China Internet Network Information Center (CNNIC) 2010, Di 26 ci Zhongguo hulian wangluo fazhan zhuangkuang tongji baogao [Twenty-Sixth Statistical Survey Report on China's Internet Development]. 15 July. Online, available: http://www.cnnic.cn/html/Dir/2010/07/15/5921.htm [accessed 8 February 2012].

'China's “Iron Man” An Undying Legend' 2009, Xinhua News Agency. 16 Sept. Online, available: http://english.sina.com/china/2009/0916/271032.html [accessed 8 February 2012].

'Chinese Women Go “Crazy' For Cosmetics' 2005, China Daily. 7 June. Online, available: http://www.chinadaily.com.cn/english/doc/2005-06/07/content_449333.htm [accessed 8 February 2012].

Clark, P. 2008, The Chinese Cultural Revolution: A History. Cambridge \& New York: Cambridge University Press.

'Cui Jian' 2009, Ouxiang. Online, available: http://news.sohu.com/s2009/9616/s266485448/ [accessed 8 February 2012].

Darnell, E., \& McGrath, T. (dirs.) 2008, Madagascar 2 (Escape 2 Africa), motion picture, DreamWorks Animation/Pacific Data Images.

Davies, D. J. 2007, 'Visible Zhiqing: The Visible Culture Of Nostalgia Among China's Zhiqing Generation, in C. K. Lee and G. Yang (eds) Envisioning the Chinese Revolution: The Politics and Poetics of Collective Memories in Reform China. Stanford: Stanford University Press, pp. 166-92.

'Dong Cunrui' n.d., Chinese Posters Foundation. Online, available: http://chineseposters.net/themes/dongcunrui.php [accessed 8 February 2012]. 
'Dong Cunrui' 2007, 80 ${ }^{\text {th }}$ Anniversary of the Founding of PLA 1927-2007, China Military Online, 27 July. Online, available: http://item.chinamil.com.cn/site2/special-reports/200707/12/content 875676.htm [accessed 8 February 2012].

'Dong Cunrui (DVD)' 2008, Ebay. Online, available: www.catalog.ebay.com/Dong-Cunrui/70963004? fcls=1 [accessed 20 October 2009].

'Dong Cunrui, geming lieshi' [Dong Cunrui, Revolutionary Martyr] 2009, Ouxiang. Online, available: http://news.sohu.com/s2009/9616/s266376775/ [accessed 8 February 2012].

Edwards, L. P. 2010, 'Military Celebrity in China: The Evolution of "Heroic and Model Servicemen",' in L. P. Edwards and E. Jeffreys (eds) Celebrity in China. Hong Kong: Hong Kong University Press, 21-43.

Farquhar, M. 2010, 'Jet Li: “Wushu Master” In Sport and Film,' in L. P. Edwards and E. Jeffreys (eds) Celebrity in China. Hong Kong: Hong Kong University Press, 103-24.

'Footage From Banned Chinese "Pop Idol” Receives Cambridge Premiere' 2007, News and Events: University of Cambridge. 5 July. Online, available: http://www.admin.cam.ac.uk/news/dp/2007070501\# [accessed 1 June 2011].

'Geming yingxiong dianying 'Dong Cunrui' [Films of Revolutionary Heroes 'Dong Cunrui'] 1955, Dir. Guo Wei. China: Guochan dianying.

Gittings, J. 1964, 'The “Learn from the Army" Campaign,' The China Quarterly, vol 16: 153-59.

Gold, T. B. 1993, 'Go With Your Feelings: Hong Kong and Taiwan Popular Culture in Greater China,' The China Quarterly, vol. 136: 907-25.

'Harry Potter' 2009, Ouxiang. Online, available: http://news.sohu.com/s2009/9616/s266489698/ [accessed 8 February 2012].

Hom, S. K. 1998, 'Lexicon Dreams and Chinese Rock and Roll: Thoughts on Culture, Language, and Translation as Strategies of Resistance and Reconstruction,' Miami Law Review, vol. 53: 1003-18.

'How the Steel Was Tempered' 2009, Wikipedia. Online, available: http://en.wikipedia.org/wiki/How_the_Steel_Was_Tempered [accessed 8 February 2012].

'Huang Jiguang' n.d., Chinese Posters Foundation. Online, available: http://chineseposters.net/themes/huangjiguang.php [accessed 8 February 2012].

'Huang Jiguang' 2007, 80 ${ }^{\text {th }}$ Anniversary of the Founding of PLA 1927-2007, China Military Online, 27 July. Online, available: http://item.chinamil.com.cn/site2/special-reports/200707/12/content_875777.htm [accessed 1 June 2011].

'Huang Jiguang, geming lieshi' [Huang Jiguang, Revolutionary Martyr] 2009, Ouxiang. Online, available: http://news.sohu.com/s2009/9616/s266376776/ [accessed 8 February 2012].

Huat, C. B. 2004, 'Conceptualizing an East Asian Popular Culture,' Inter-Asia Cultural Studies, vol. 5, no. 2: $200-21$.

'Huitailang' 2009, Ouxiang. Online, available: http://news.sohu.com/s2009/9616/s266489497/ [accessed 8 February 2012].

“'Iron Man” Wang Jinxi' 2009, Chinese Posters Foundation. Online, available: http://chineseposters.net/themes/wangjinxi.php [accessed 8 February 2012].

Jakes, S. 2005, 'Asia’s Heroes 2005: Li Yuchun Loved for Being Herself,' TimeAsia, 3 Oct. Online, available: http://www.time.com/time/asia/2005/heroes/li_yuchun.html [accessed 8 February 2012].

Jeffreys, E. and Edwards, L. P. 2010, 'Celebrity/China,' in L. P. Edwards and E. Jeffreys (eds) Celebrity in China. Hong Kong: Hong Kong University Press, 1-20.

'Jiao Yulu' 1990, Dir. Wang Jixing, Henan, China: Eimei Film Studio.

'Jiao Yulu' 2009a, Chinese Posters Foundation. Online, available: http://chineseposters.net/themes/jiaoyulu.php [accessed 8 February 2012].

'Jiao Yulu' 2009b, Baidu.com. Online, available: http://baike.baidu.com/view/7484.htm [accessed 8 February 2012].

'Jiao Yulu, jiceng ganbu' [Jiao Yulu, Grassroots Cadre] 2009, Ouxiang. Online, available: http://news.sohu.com/s2009/9616/s266376809/ [accessed 8 February 2012].

Kong, S. 2010, 'Literary Celebrity in China: From Reformers to Rebels,' in L. P. Edwards and E. Jeffreys (eds) Celebrity in China. Hong Kong: Hong Kong University Press, 125-44.

'Lai Ning' 2009a, Chinese Posters Foundation. Online, available: http://news.sohu.com/s2009/9616/s266483291/ [accessed 8 February 2012].

'Lai Ning' 2009b, Ouxiang. Online, available: http://news.sohu.com/s2009/9616/s266483291/ [accessed 8 February 2012].

'Lei Feng' 2009, Baidu.com. Online, available: baike.baidu.com/view/1753.htm [accessed 8 February 2012].

'Lei Feng chuanren' [Lei Feng's Legacy] n.d., Lei Feng Jinianguan [Lei Feng Memorial Museum], Leifeng.org.cn. Online, available: http://www.leifeng.org.cn/1073.asp [accessed 8 February 2012]. 
Lei Feng Heritage for the Whole World' 2009, Danwei. 5 March. Online, available: http://www.danwei.org/people/lei_feng_2009.php [accessed 8 February 2012].

'Lei Feng, putong shibing' [Lei Feng, Common Soldier] 2009, Ouxiang. Online, available: http://news.sohu.com/s2009/9616/s266376807/ [accessed 8 February 2012].

'Li Lianjie' [Jet Li] 2009, Ouxiang. Online, available: http://news.sohu.com/s2009/9616/s266442910/ [accessed 8 February 2012].

'Li Tiemei, xiqu renwu' [Li Tiemei, Opera Character] 2009, Ouxiang. Online, available: http://news.sohu.com/s2009/9616/s266376865/ [accessed 8 February 2012].

Li Qiaoyi 2009, 'No Laughing Matter,' Global Times. 10 June. Online, available: http://business.globaltimes.cn/top-photo/2009-06/436142.html [accessed 8 February 2012].

Liu, G. 2009, 'Changing Chinese Migration Law: From Restriction to Relaxation,' Journal of International Migration and Integration, vol. 10: 311-33.

'Liu Huifang' 2009, Ouxiang. Online, available: http://news.sohu.com/s2009/9616/s266486435/ [accessed 8 February 2012].

'Liu Hulan, geming lieshi' [Liu Hulan, Revolutionary Martyr] 2009, Ouxiang. Online, available: http://news.sohu.com/s2009/9616/s266376777/ [accessed 8 February 2012].

'Liu Hulan: The Youngest Female CPC Member Died in the Revolution' 2007, All-China Women's Federation. 9 April. Online, available: http://www.womenofchina.cn/html/report/82884-1.htm [accessed 8 February 2012].

'Liuxing huayuan' [Meteor Garden] 2009, Ouxiang. Online, available: http://news.sohu.com/s2009/9616/s266488994/ [accessed 8 February 2012].

'Luo Dayou' 2009, Ouxiang. Online, available: http://news.sohu.com/s2009/9616/s266485658/ [accessed 8 February 2012].

'Maike'er Jiekexun' [Michael Jackson] 2009, Ouxiang. Online, available: http://news.sohu.com/s2009/9616/s266484263/ [accessed 8 February 2012].

'Maike'er Qiaodan' [Michael Jordan] 2009, Ouxiang. Online, available: http://news.sohu.com/s2009/9616/s266486757/ [accessed 8 February 2012].

'Meilinkai aishi' [Mary Kay Ash] 2009, Ouxiang. Online, available: http://news.sohu.com/s2009/9616/s266487038/ [accessed 8 February 2012].

'Mixed Memories Of “Zhiqing”' 2004, Shanghai Star. 15 June.

Moskowitz, M. L. 2009, 'Mandopop Under Siege: Culturally Bound Criticisms Of Taiwan's Pop Music,' Popular Music, vol. 28, no. 1: 69-83.

'Ouxiang jinhualun' [Evolution of the Idol] 2009, Ouxiang. Online, available: http://news.sohu.com/s2009/9616/s266376614/ [accessed 8 February 2012].

'Quanguo “shuangbai” pingxuan' [China's Top ‘Double Hundred' Personages] 2009, People’s Daily. Online, available: http://shuangbai.people.com.cn/GB/158065/158687/index.html [accessed 8 February 2012].

Redmond, S. \& Holmes, S. (eds.) 2007, Stardom and Celebrity. London: Sage.

'Sanmao' 2009, Ouxiang. Online, available: http://news.sohu.com/s2009/9616/s266443680/ [accessed 8 February 2012].

'Shang ganling' [Battle on Shangganling Mountain] 1956, Dir. Shan Lin \& Meng Sha, Feature Film, China: Changchun dianying zhipianchang.

Sheridan, M. 1968, 'The Emulation of Heroes,' The China Quarterly, vol. 33: 47-72.

'Shi Chuanxiang' 2008, China Film Group. Online, available: http://exp.chinafilm.com/Movies/drama/200804/412.html [accessed 8 February 2012].

'Shi Chuanxiang, taofen gongren' [Shi Chuangxiang, Nightsoil Worker] 2009, Ouxiang. Online, available: http://news.sohu.com/s2009/9616/s266376806/ [accessed 8 February 2012].

‘Shizhi (Guo Lusheng), shiren' [Guo Lusheng (Alias Shizhi), Poet] 2009, Ouxiang. Online, available: http://news.sohu.com/s2009/9616/s266376868/ [accessed 8 February 2012].

Song Hongmei 2009, 'Pleasant Goat Boosts China's Animation Industry,' China Daily. 3 May.

'Sun Daolin, dianying yanyuan' [Sun Daolin, Film Actor] 2009, Ouxiang. Online, available: http://news.sohu.com/s2009/9616/s266376778/ [accessed 8 February 2012].

Teiren [Iron Man] 2009, Feature film, Beijing, China: Zijingcheng Yingye Limited.

The Official Jet Li Website 2010, Jetli.com. Online, available: http://jetli.com/jet/index.php?s=spirit\&ss=projects\&p=one [accessed 8 February 2012].

Turner, G. 2009, Ordinary People and the Media: The Demotic Turn Thousand Oaks, CA: Sage.

'Wang Jinxi, shiyou gongren' [Wang Jinxi, Oil Field Worker] 2009, Ouxiang. Online, available: http://news.sohu.com/s2009/9616/s266376808/ [accessed 8 February 2012].

Wang, M. and Singhal, A. 1992, 'Kewang, A Chinese Television Soap Opera With A Message,' Gazette, vol. 49: 177-92. 
‘Wang Shuo' 2009, Ouxiang. Online, available: http://news.sohu.com/s2009/9616/s266485998/ [accessed 8 February 2012].

Williams, C., \& Howard, B. (dirs.) 2008, Bolt, motion picture, Walt Disney Pictures.

'Xiaohudui' [Little Tigers] 2009, Ouxiang. Online, available: http://news.sohu.com/s2009/9616/s266485075/ [accessed 8 February 2012].

'Xu Sanduo' 2009, Ouxiang. Online, available: http://news.sohu.com/s2009/9616/s266498743/ [accessed 8 February 2012].

'Yang Zirong memorial commentary' 2008, Hailintour.com. Online, available: http://www.hailintour.com/view.asp?id=529 [accessed 8 February 2012].

'Yang Zirong, zhandou yingxiong' [Yang Zirong, Combat Hero] 2009, Ouxiang. Online, available: http://news.sohu.com/s2009/9616/s266376866/ [accessed 8 February 2012].

'Zhang Haidi' 2009, Ouxiang. Online, available: http://news.sohu.com/s2009/9616/s266443539/ [8 February 2012].

'Zhang Hua' 2009, Ouxiang. Online, available: http://news.sohu.com/s2009/9616/s266483993/ [accessed 8 February 2012].

'Zhang Hua' n.d., Chinese Posters Foundation. Online, available: http://chineseposters.net/themes/zhanghua.php [accessed 8 February 2012].

Zhang, Lijia 2002, 'Mad Dog: The Legend of Chinese Poet Guo Lusheng,' Manoa, vol. 14, no. 1: $105-13$.

Zhang Ming'ai 2007, 'Shibing tuji [Soldier Sortie],' China.org.cn, 1 Oct. Online, available: http://www.way2english.com/main/ArticleContent.asp?ID=2374 [accessed 2 October 2009].

Zhang Shun 2005, 'Zhang Haidi Encourages the Disabled,' Southcn.com. 11 May. Online, available: http://www.newsgd.com/culture/peopleandlife/200505110055.htm [accessed 8 February 2012].

Zheng, W. 2008, 'National Humiliation, History Education, and the Politics of Historical Memory: Patriotic Education Campaigns In China,' International Studies Quarterly, vol. 52: 783-806.

'Zhiqu weihu shan' [Taking Tiger Mountain By Strategy] 1970, Feature Film. Beijing, China: Zijingcheng Yingye Limited.

'Zhou Jielin' 2009, Ouxiang. Online, available: http://news.sohu.com/s2009/9616/s266488905/ [accessed 8 February 2012].

'Zhou Xingchi: xiaozhong dailei de xiju zhiwang' [Stephen Chow: The King Of Comedy Bringing Sorrow In Laughter] 2009, Ouxiang. Online, available: http://news.sohu.com/s2009/9616/s266486135/ [accessed 8 February 2012].

'Zhuixun xiandai Zhongguo' [The Search for Modern China] 2009, Sohu.com. Online, available: http://news.sohu.com/s2009/guoqing60/ [accessed 8 February 2012]. 